DOI: $10.17516 / 1997-1370-0723$

УДК $159.9+316.6$

\title{
On the Relationship Between Uncertainty Tolerance and Hardiness in Adolescents
}

\author{
Olga O. Andronnikova* \\ Novosibirsk State Pedagogical University \\ Novosibirsk, Russian Federation
}

Received 25.02.2021, received in revised form 04.03.2021, accepted 12.03.2021

\begin{abstract}
Objective - identify the relationship between the phenomena of uncertainty tolerance and hardiness in adolescents.

Uncertainty tolerance (UT) is understood as a personality trait that manifests itself in an ability to accept uncertainty and act confidently in unstable situations. Adolescence is characterized as a period of instability. It is thus assumed that uncertainty tolerance is a significant parameter in the structure of adolescents' hardiness.

The research was designed to identify the relationship between uncertainty tolerance and hardiness in adolescents using Spearman's rank correlation coefficient.

Survey respondents: 66 schoolchildren in grades 9 and 11 (15-18 years old), of which 34 are boys and 32 are girls.

For the research, a set of methods was used. Hardiness Survey (S. Maddi adapted by D.A. Leont'ev); McLane's Multiple Stimulus Types Ambiguity Tolerance Scale-I ((MSTAT-I) adapted by E. G. Lukovitskaia); Adaptive behavioural strategies Questionnaire (adolescent form: ASP-1) by N.N. Mel'nikova.

The results of the research indicate that the relationship between uncertainty tolerance to and the scales $(\mathrm{p} \leq 0.0001)$ of Risk Acceptance $(\mathrm{r}=0.75)$, Control $(\mathrm{r}=0.71)$, Engagement $(\mathrm{r}=0.65)$, Vitality $(\mathrm{r}=0.65)$ has been determined.

Empirical data contribute to the understanding of uncertainty tolerance as a basic personality trait that contributes to the effective organization of life with a limited amount of information about future events. Building hardiness enables adolescents to cope with age-related challenges in a more efficient way.
\end{abstract}

Keywords: tolerance to uncertainty, hardiness, adolescence, adaptation.

Research area: pedagogy.

Citation: Andronnikova, O.O. (2021). On the relationship between uncertainty tolerance and hardiness in adolescents. J. Sib. Fed. Univ. Humanit. Soc. Sci., 14(3), 320-326. DOI: 10.17516/1997-1370-0723.

\footnotetext{
(C) Siberian Federal University. All rights reserved

* Corresponding author E-mail address: andronnikova_69@mail.ru ORCID: 0000-0002-1756-7682
} 


\title{
Толерантность к неопределенности и ее связь с жизнестойкостью у подростков
}

\author{
0.0. Андронникова \\ Новосибирский государственный педагогический университет \\ Российская Федерачия, Новосибирск
}

\begin{abstract}
Аннотация. Цель статьи - выявление взаимосвязи между феноменами толерантности к неопределенности и жизнестойкости в подростковом возрасте.

Толерантность к неопределенности (UT) понимается как черта личности, которая проявляется в способности принимать неопределенность и достаточно уверенно действовать в нестабильных жизненных ситуациях. Так как подростковый возраст характеризуется как период нестабильности, возникло предположение, что толерантность к неопределенности выступает значимым параметром в структуре жизнестойкости подростков.

Дизайн исследования предполагал выявление взаимосвязи между толерантностью к неопределенности и жизнестойкостью подростков при помощи коэффициента ранговой корреляции Спирмена.

Выборка исследования: школьники 9-х и 11-х классов в количестве 66 человек (1518 лет), из них 34 мальчика и 32 девочки.

Для проведения исследования использовался комплекс методик: тест жизнестойкости (С. Мадди, адаптация Д. А. Леонтьева); опросник толерантности к неопределенности МакЛейна ((MSTAT-I) адаптация Е.Г. Луковицкой); опросник «Адаптивные стратегии поведения» (подростковая форма: АСП-1) Н.Н. Мельниковой.

Результаты проведенного исследования свидетельствуют о выявлении взаимосвязей между толерантностью к неопределенности и шкалами $(\mathrm{p} \leq 0,0001)$ «Принятие риска» $(\mathrm{r}=0,75)$, «Контроль» $(\mathrm{r}=0,71)$, «Вовлеченность» $(\mathrm{r}=0,65)$, «Жизнестойкость» $(\mathrm{r}=0,65)$.

Эмпирические данные способствуют пониманию толерантности к неопределенности как базовой черты личности, способствующей эффективной организации жизнедеятельности при ограниченном количестве информации о будущих событиях. Повышение жизнестойкости позволяет подросткам более эффективно справляться с задачами возраста.
\end{abstract}

Ключевые слова: толерантность к неопределенности, жизнестойкость, подростковый возраст, адаптация.

Научная специальность: 13.00.00 - педагогические науки.

\section{Introduction}

The modern world is highly unpredictable and uncertain. The tension and anxiety of modern reality and the growing occurrence of unpredictable situations explain the fear of crisis, instability and rapid changes in culture and society (Zinchenko, 2007). Fear of change gives rise to a sense of uncertainty, which contributes to the growth of internal anxiety. In a situation of continuous uncertainty, one may experience anxiety or refuse to make decisions and act. One's ability to endure stressful situations without losing internal balance or without impact on the success of their activities is called hardiness (Fominova, 2012; Liu, Zhang \& Huang, 2020; Moffett et al., 2021). Tolerance to uncertainty is an important quality that does not only stabilize the personality but also opens opportunities for a new experience and adequate actions in situations of uncertainty 
(Zinchenko, 2007). Thus, we may assume that uncertainty tolerance is associated with hardiness, which is especially important in the light of adolescence and its acute problems that need to be solved in the modern situations of mass shocks and pandemic.

\section{Formulation of the problem}

In literature psychology, a lot of attention is paid to the issues of intolerance of uncertainty. The Intolerance of Uncertainty (IU) has a different definition. In the modern approach, it is understood as the incapability of enduring a frightening reaction caused by an alleged lack of important, key or sufficient information and supported by an appropriate perception of uncertainty (Carleton, 2016). Intolerance of uncertainty lies upon the fear of the unknown that triggers a mechanism that leads to the onset and maintenance of anxiety and depression (Carleton, 2016; Osmanağaoğlu, Creswell \& Dodd, 2018). Examining the factors underlying intolerance of uncertainty reveals the cognitive skills needed to detect and respond to uncertainty from a young age (Lyons, Ghetti, 2013). However, adolescence is becoming an important stage in the development of intolerance of uncertainty.

Uncertainty tolerance (UT) is understood as a personality trait that manifests itself as an ability to accept uncertainty and act confidently in unstable life situations, associated with openness to new experience and new meanings (Koerner \& Dugas, 2008). Uncertainty tolerance can be considered as an individual trait, as a psychological attitude of the person, and as an emotional reaction to the unknown (Mirimanova, Obukhov, 2001). Hillen, Gutheil, Strout, Smets, \& Han (2017) interpret uncertainty tolerance as a set of psychological reactions (cognitive, emotional and behavioural) arising in response to the ignorance of certain aspects of the world. On the other hand, one can view uncertainty tolerance as a condition determined by situational or contextual factors that need to be measured and taken into account (Herman et al., 2010).

Tolerance to uncertainty as a personality trait is associated with manifestations of sub- jectivity, the presence of meanings and values in a person's life.

The phenomenon of tolerance to uncertainty is mainly a socio-psychological direction that contains an emotional, cognitive and behavioural component. The first is the conscious experience of the surrounding world and, according to E. G. Lukovitskaia (2003), is negative, as it significantly reduces the level of uncertainty tolerance. Being the degree of uncertainty awareness, the cognitive component allows a person to compose semi-structured information and get open to something new. The last component is individual originality and a tendency to act in a certain way under uncertain conditions.

Growing tolerance for uncertainty, for people and the environment increases confidence and hardiness to stressful situations (Iannello et al., 2017). It is the basic principle of survival at the present stage of human development as a social subject of life. This phenomenon is classified based on two criteria: external tolerance to uncertainty, i. e., the position of the individual where situations or objects are observed from different aspects, with account for different conditions; and internal tolerance to uncertainty, i. e., the ability to make a clear decision in a problematic situation with a lack of information about its possible results (Gusev, 2007). Uncertainty tolerance is characterized by a combination of skills and abilities for planning, self-control and anticipation of results. In this respect, tolerance is resistance to the influence of conditions of uncertainty in both the internal and external environment and the ability to relieve emotional stress to uncertainty.

Hardiness (endurance, resilience) is usually understood as a personality trait associated with one's ability to endure stressful situations without losing internal balance and without an impact on the success of their activities, including the ability to apply adequate ways of coping with stress in difficult situations, which leads to individual development (Fominova, 2012). The dynamism of self-regulation, skills and abilities in solving life problems are important components of hardiness required for successful adaptation in difficult situations. Hardiness 
is an important prerequisite for adaptation and growth in critical and unstable conditions, as well as for psychological well-being (Shuvalov, 2011). It is also a trait associated with possible subjective resources and abilities manifested in one's coping with difficult situations and solving urgent life issues in social relationships (Bang, 2016). As we can see in the published papers, higher hardiness plays a key role in reducing stress, depression and anxiety, being negative risk factors (Kim, 2016). Consequently, higher hardiness can lead to a lower intolerance for uncertainty.

It is especially important to research the relationship of tolerance to uncertainty and hardiness in adolescents since this is the age of significant qualitative and quantitative changes, new life situations the young person has had no experience with and new internal transformations. In other words, due to the specificity of age, a teenager is already in a situation of uncertainty. Growing up in an unstable world amplifies this uncertainty. It is important for a teenager to be able to deal with uncertainty, to be able to make adequate and life-changing decisions.

Developed hardiness can help a teenager overcome the difficulties of adolescence and adapt to the changing world, make plans for an uncertain future.

At the same time, the problem of the relationship between uncertainty tolerance and hardiness in adolescents has not been sufficiently studied in psychology. This explains the urgency of this problem.

Thus, the objective of the research is to identify and study the nature of the relationship between the phenomena of uncertainty tolerance and hardiness in adolescents.

\section{Research methods}

To identify the level of hardiness and uncertainty tolerance in adolescent students, the following psychodiagnostics techniques were applied: Hardiness Survey (S. Maddi, adapted by D. A. Leont'ev (Leont'ev, Rasskazova, 2006); Multiple Stimulus Types Ambiguity Tolerance Scale-I (MSTAT-I), adapted by E. G. Lukovitskaia (Leont'ev, Osin, Lukovitskaia, 2016); Adaptive Behavioural Strate- gies Questionnaire (adolescent form: ASP-1) by N.N. Mel'nikova (Mel'nikova, 2004). As a method of mathematical statistics, Spearman's rank correlation coefficient was used. The research was conducted at a municipal budgetary educational institution in the city of Novosibirsk. The survey covered 66 schoolchildren in grades 9 and 11 (15-18 years old), 34 boys and 32 girls.

\section{Results}

The initial analysis of the results allows us to conclude that in this sample, adolescents demonstrate an average "general hardiness»" value, which means that the adolescents are not absolutely confused, but at the same time, are not particularly self-confident either. According to the MSTAT-I method, the subjects were found to have both «tolerance for uncertainty» (38.2) and «intolerance for uncertainty» $(-27.4)$. This means that the «tolerance for uncertainty» value is average, i. e., the adolescents partially accept the ambiguity of the world around them, which is manifested in an independent desire and readiness to solve complex life problems. The analysis of the obtained results with the adaptation method for adolescents (ASP 1) by Mel'nikova N.N. showed that among the correspondents, the following scales are the most pronounced: "Active self-change» (7.7), «Passive expectation of internal changes» (2.8), «Passive obedience to environmental conditions» (2.6), while the least pronounced one is «Search for a new environment» (0.9), «Passive self-representation» $(-0.5)$. The adolescents demonstrated the optimal level of adaptation in the environment by consciously changing their perception of life situations and the basis of acceptable forms of behaviour. As a rule, this type of change is stable.

Next, let us consider the statistical relationship between the parameters of tolerance to uncertainty measured using the McLane questionnaire (MSTAT-I) adapted by E. G. Lukovitskaia, hardiness measured by the method of S. Muddy adapted by D. A. Leont'ev and the method of adaptation (ASP 1) by N. N. Mel'nikova. The correlations discovered in the group of adolescents are presented in Table 1. 
Olga O. Andronnikova. On the Relationship Between Uncertainty Tolerance and Hardiness in Adolescents

Table 1. Relationships between the investigated parameters of diagnostic techniques

\begin{tabular}{|l|c|c|}
\hline \multicolumn{1}{|c|}{ The investigated parameter } & Spearman's r-test & Significance level (p) \\
\hline Uncertainty tolerance and engagement & 0.75 & $0.001^{* * *}$ \\
\hline Uncertainty tolerance and control & 0.71 & $0.001^{* * *}$ \\
\hline Uncertainty tolerance and risk acceptance & 0.65 & $0.001^{* * *}$ \\
\hline Uncertainty tolerance and hardiness & 0.86 & $0.001^{* * *}$ \\
\hline Uncertainty tolerance and passive expectation of internal change & -0.26 & $0.05^{*}$ \\
\hline Involvement and immersion in the inner world & -0.32 & $0.02^{*}$ \\
\hline Control and immersion in the inner world & -0.26 & $0.04^{*}$ \\
\hline Control and passive representation & 0.29 & $0.03^{*}$ \\
\hline Hardiness and engagement & -0.31 & $0.02^{*}$ \\
\hline
\end{tabular}

In the course of the correlation analysis (Spearman's r-criterion) in the group of adolescents from grades 9 and 11, nine significant relationships were identified, five of which were positive and four were negative.

The results of the research demonstrate the presence of strong relationships between the following parameters:

The uncertainty tolerance scale is interrelated with the risk acceptance scale $(\mathrm{r}=0.75$ at $\mathrm{p} \leq 0.0001$ ). This positive relationship indicates that adolescents having limited access to information due to the uncertainty in the rapidly changing and uncontrollable life situations cannot predict any future events. As a result, the students who take the uncertain conditions positively, are ready to apply risky actions without reliable guarantees of success or failure.

The tolerance to uncertainty scale correlates with the control scale $(r=0.71$ at $p$ $\leq 0.0001)$. This suggests that in a moment of uncertainty the young people feel independence and responsibility, and to their best to control their lives instead of avoiding challenges.

The tolerance to uncertainty scale correlates with the engagement scale $(r=0.65$ at $\mathrm{p} \leq 0.0001)$. The positive relationship means that the teenagers forced to act in an uncertain context navigate unfamiliar situations with the help of engagement to find many interesting things for life and themselves.

The uncertainty tolerance scale is interconnected with the hardiness scale $(r=0.65$ at $\mathrm{p} \leq 0.0001)$. The discovered direct relationship shows that at a moment of uncertainty and under the pressure of the external environment, the adolescents are capable of making the right decision in a confident manner, taking the initiative to overcome challenges and finding a way out of difficult life circumstances. As a personal resource, hardiness enables learners to respond to changes, overcome anxiety, stress, and manage the current changes. Proceeding from this, uncertain situations can be stabilized as the teenager develops the ability to function successfully in social systems. Thus, the higher the uncertainty tolerance, the hardier the person is, and vice versa.

The tolerance to uncertainty scale is interconnected with the passive expectation of internal changes scale $(r=-0.26$ at $p \leq 0.05)$. The higher the tolerance to uncertainty, the lower the passive expectation of internal changes, engagement, and immersion into the inner world would be $(r=-0.32$ at $p \leq 0.02)$. The obtained negative relationship indicates that the students are actively involved in learning and any other activities, developing a positive attitude to be satisfied with the work and to get it done effectively. This way it is unacceptable for a teenager to close in and deeply immerse into his inner world. In other words, the more students are involved in the world around them and the more they enjoy it, the less they withdraw into themselves and their inner experiences.

The control and immersion in the inner world scales $(r=-0.26$ at $p \leq 0.04)$. The re- 
sulting negative relationship suggests that the adolescents with well-developed control are capable of overcoming challenges, sensing satisfaction and indispensability through planning their time and actions in dramatic change periods. An obstacle for teenagers in overcoming difficult circumstances would be living in their inner world and experiences. As they lock themselves in strong fantasies, they lose connection with reality. Control, passive representation scales $(r=0.29$ at $p$ $\leq 0.03$ ).

The obtained positive relationship indicates that, in a period of the unknown, the adolescents can cope with stress and anxiety by collecting information, which increases their level of control over uncertain situations. Stubbornly defending their opinion, even without changing the reality, the future results may become predictable and the future becomes more specific.

Hardiness and immersion in the inner world scales $(r=-0.31$ at $p \leq 0.02)$. This relationship indicates that the students cope with stressful situations and do not pay much attention to their significance and, in particular, they are eager to look for new opportunities without cutting contacts with frustrating environments.

\section{Conclusion}

Thus, there is a wide range of ideas about the uncertainty tolerance phenomenon, which is reduced to a positive attitude of the individual towards uncertain situations. As a personality trait, uncertainty tolerance is manifested through sensitivity, flexibility and openness to new experience, confidence and activity in familiar and unfamiliar situations. In other words, uncertainty tolerance is a basic personality trait required for organizing life with a limited amount of information about future events.

Hardiness refers to the ability of adolescents to cope with tasks and overcome life challenges. Based on this ability, young people develop a positive attitude, justified by the productivity and expediency of the work they do.

Empirical research discovered a relationship between uncertainty tolerance and hardiness in adolescents.

The research results can serve as the basis for programs intended to increase uncertainty tolerance. The identified positive relationships allow teaching adolescents how to cope with the uncertainty of the modern world, which inevitably means uncertainty about the future.

\section{References}

Bang, J.H. (2016). The effects of smartphone addiction management application on self-regulation and interpersonal relationship ability of university students [in Korean]. In J Korea Entertain Industry Assoc., 10(2), 323-337. DOI:10.21184/jkeia.2016.04.10.2.323

Carleton, R.N. (2016). Into the unknown: A review and synthesis of contemporary models involving uncertainty. Journal of anxiety disorders, 39, 30-43. DOI: 10.1016/j.janxdis.2016.02.007

Fominova, A.N. (2012). Zhiznestoykost' lichnosti [Hardiness of the individual]. Moscow, Moscow State Pedagogical University, Prometheus, $151 \mathrm{p}$.

Gusev, A.I. (2007). K probleme izmereniia tolerantnosti k neopredelennosti [To the problem of measuring tolerance to uncertainty]. In Prakticheskaia psikhologiia i sotsial'naia rabota [Practical psychology and social work], 1, 21-28.

Herman, J.L., Stevens, M.J., Bird, A., Mendenhall, M.E., \& Oddou, G. (2010). The tolerance for ambiguity scale: Towards a more refined measure for international management research. In International Journal of Intercultural Relations, 34, 58-65.

Hillen, M.A., Gutheil, C.M., Strout, T.D., Smets, E., \& Han, P. (2017). Tolerance of uncertainty: Conceptual analysis, integrative model, and implications for healthcare. In Social science \& medicine (1982), 180, 62-75. DOI: 10.1016/j.socscimed.2017.03.024

Iannello, P., Mottini, A., Tirelli, S., Riva, S., \& Antonietti, A. (2017). Ambiguity and uncertainty tolerance, need for cognition, and their association with stress. A study among Italian practising physicians. In Medical education online, 22(1), 1270009. DOI: 10.1080/10872981.2016.1270009 
Iapparova, Ia. (2019). Tolerantnost' $\mathrm{k}$ neopredelonnosti v sviazi s mirovozzrencheskimi ustanovkami [Tolerance to uncertainty in connection with worldview attitudes]. In Psikhologicheskoe prosveshchenie [Psychological education], 145-161.

Kim, J.A. (2016). The effects of resilience on adjustment to college and career barriers of college students majoring in secretarial studies [In Korean]. J Secret Studies, 25(1), 161-183.

Koerner, N., \& Dugas, M.J. (2008). An investigation of appraisals in individuals vulnerable to excessive worry: The role of intolerance of uncertainty. In Cognitive Therapy and Research, 32(5), 619-638. DOI: $10.1007 / \mathrm{s} 10608-007-9125-2$

Leont'ev, D.A., Osin, E.N., Lukovitskaia, E.G. (2016). Diagnostika tolerantnosti k neopredelennosti. Shkaly D. Makleyna [Diagnostics of tolerance to uncertainty. D. MacLane's scale]. Moscow, Smysl, 55 p.

Leont'ev, D.A., Rasskazova, E.I. (2006). Test zhiznestoykosti [Hardiness test]. Moscow, Sense, 63 p.

Liu, M., Zhang, H., \& Huang, H. (2020). Media exposure to COVID-19 information, risk perception, social and geographical proximity, and self-rated anxiety in China. In BMC public health, 20(1), 1649. DOI: 10.1186/s12889-020-09761-8

Lukovitskaia, E.G. (2003). Sotsial'no-psihologicheskoe znachenie tolerantnosti k neopredelennosti [Socio-psychological significance of tolerance to uncertainty]. Cand. psychol. sciences, RSL, $18 \mathrm{p}$.

Lyons, K.E. and Ghetti, S. (2013). I don't want to pick! Introspection on uncertainty supports early strategic behaviour. In Child Dev, 84, 726-736. DOI: 10.1111/cdev.12004

Mel'nikova, N.N. (2004). Diagnostika sotsial'no-psikhologicheskoy adaptatsii lichnosti [Diagnostics of the socio-psychological adaptation of the individual]. Textbook, Chelyabinsk, SUSU Publishing House, $57 \mathrm{p}$.

Mirimanova, M.S., Obukhov, A.S. (2001). Vospitanie tolerantnosti cherez sotsiokul'turnoe vzaimodeystvie [Education of tolerance through socio-cultural interaction]. In Razvitie issledovatel'skoy deiatel'nosti uchashchikhsia [Development of research activities of students], 88-98. Available at: http://psylib.org. ua/books/leona01/

Moffett, J., Hammond, J., Murphy, P., \& Pawlikowska, T. (2021). The ubiquity of uncertainty: a scoping review on how undergraduate health professions' students engage with uncertainty. In Advances in health sciences education: theory and practice, 1-46. Advance online publication. DOI: 10.1007/s10459021-10028-z

Osmanağaoğlu, N., Creswell, C., \& Dodd, H.F. (2018). Intolerance of Uncertainty, anxiety, and worry in children and adolescents: A meta-analysis. In Journal of Affective Disorders, 225, 80-90. DOI: 10.1016/j. jad.2017.07.035

Shuvalov, A.V. (2011). Problemy razvitiia sluzhby psikhologicheskogo zdorov'ia v sisteme dopolnitel'nogo obrazovaniia detey [Problems of development of psychological health service in the system of additional education for children]. In Voprosy psikhologii [Questions of psychology], 6, 6-79.

Zinchenko V.P. (2007). Tolerantnost' k neopredelennosti: novost' ili psikhologicheskaia traditsiia? [Tolerance to uncertainty: news or psychological tradition?]. In Chelovek $v$ situatsii neopredelennosti [A person in a situation of uncertainty]. Theis, 6, 9-33. 